Journal of Engineering and Applied Sciences 15 (2): 479-491, 2020

ISSN: 1816-949X

(C) Medwell Journals, 2020

\title{
Barcode Parking System for Majlis Perbandaran Malaysia
}

\author{
${ }^{1}$ Mohamad Zul Helmi Azilla, ${ }^{1}$ Nor Azlina Ali and ${ }^{2}$ Faridah Yahya \\ ${ }^{1}$ Department of Software Engineering, Malaysian Institute of Information Technology, \\ ${ }^{2}$ Department of Computer Engineering, Malaysian Institute of Information Technology, \\ Universiti Kuala Lumpur, Malaysia
}

\begin{abstract}
This is a prototype project for Malaysian Agency in Malaysia. Its named as barcode parking system for Majlis Perbandaran. Objective of the project is to integrate and replace the current system that was using coupon as their parking ticket. The barcode system is an idea taken from coupon parking system that required people to park a vehicle around the town and must show the coupon as ticket parking. Problem from this system mainly is the coupon ticket itself where one coupon represent one hour and required more than one coupon for the rest of the hours. Barcode parking system is one of the problem solving method which use a technology of barcode to represent as parking ticket in this project. Barcode parking system developed for both mobile and website application. This project is an application which requires installation on mobile phones and use to pay their parking ticket anywhere and any time they want without using coupon to display on their vehicle. This application make it easy for people to update their parking ticket without having go to their vehicle and payment made through electronic transaction. Without the use of paper, barcode parking system also indirectly contribute to green life style adopted in Malaysia.
\end{abstract}

Key words: Barcode, parking system, mobile application, automate, application, website

\section{INTRODUCTION}

Currently, technology has to skip a level that is higher than the 19th century reforms that created a facility for all the community in solving the problem of daily routine. This was no exception in the growth of technology in mobile applications where in the past only used as a hub by voice. The technology involve hardware and software embedded together with the internet which can be found in the phone such as cameras, wireless internet, applications in android platform as well as iOS and touch-screen technology.

Paying for mparking a vehicle can be a hassle for some people. City councils in some part of Malaysia (BPS., 2019; Anonymous, 2016) still use the scratch and display coupon ticket for parking while others used the parking machines (Nair, 2017; Bernama, 2019) which use coins and card payments. According to report in the USA (Paul and Bergeron, 2015) barcode parking technology installed in residential areas help to make residents feel safer and happier. Group of researchers from India (Patel et al., 2015; Mudey and Rojatkar, 2015; Nikhitkumar et al., 2015) focused on the hardware development of the parking not on the application software in managing the system developed. Findings by Mogarkar and Gulhane (2016) reported that using RFID technology make the parking lot management operation cheaper and faster. They focused more on automation and controlling of the parking system. Using the same technology, other researchers (Dorjee et al., 2016; Bhosale et al., 2015; Patel et al., 2015; Dogo et al., 2016) also concluded that the system make the process of authentication faster and efficient in reducing waiting time. One of the application use a prepaid method of payment. Both application system do not focus on the user interface of the system but more on hardware implementation. A QR code parking locator developed by Tekade et al. (2017) can only register the user and provide parking space for users. Another finding by researcher is using positioning method (Song and Lee, 2016) of blackbox camera and a two dimensional barcode for indoor parking lot.

This project study propose a parking system using barcode for the local city council in Malaysia. The system use the barcode as the method to pay the parking fee instead of using coupon ticket. Current parking system (Ch'ng, 2017) employed by majority of the City Council Agency in Malaysia is using coupon ticket. Summons are issued for not displaying these coupons. The coupon ticket priced at RM6.00 per book. The current system used by the agency has one vulnerability where user who want to park their vehicle, need to provide more than one coupon ticket to display on the vehicle. It is difficult for the city council enforcement officers to check the coupon ticket validity because many coupon tickets displayed on the vehicles.

To solve the problem, it is proposed to implement a barcode parking system to replace the current conventional parking system. The system is in a form of application suitable for mobile phone users. It can help users to update their coupon ticket online and for the enforcement officer's agency to validate the displayed 

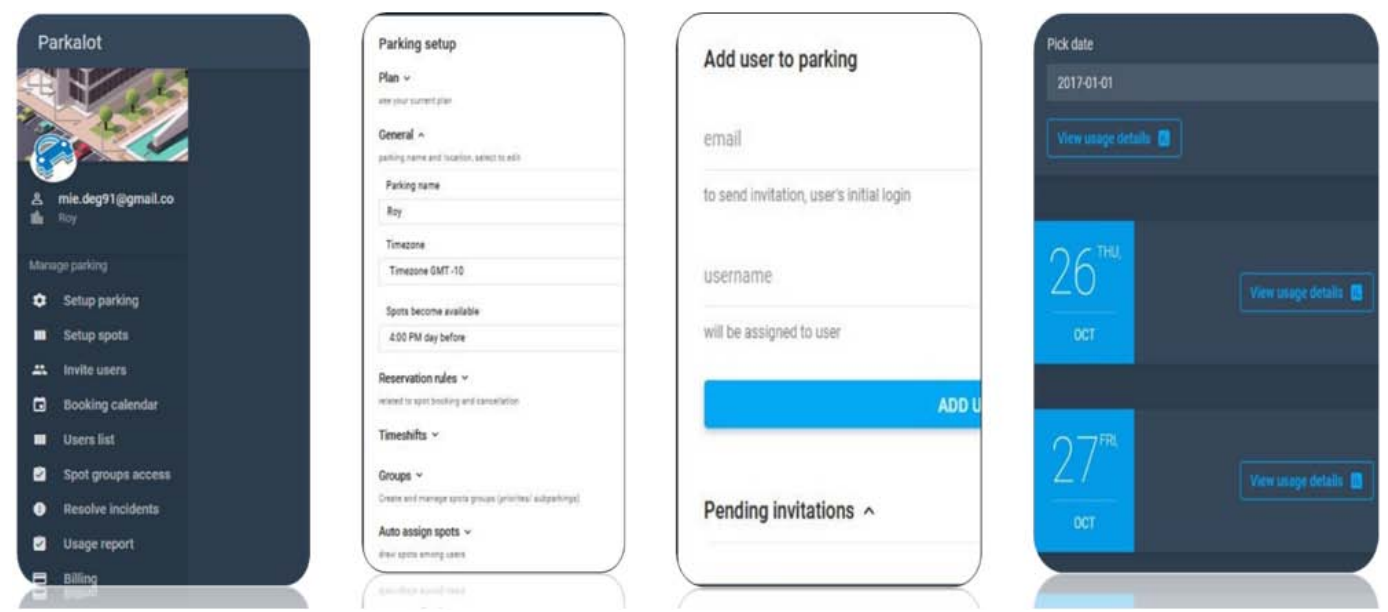

Fig. 1: Parkalot.io system screen capture (Parkalot, 2019)

coupon tickets. The application system make use of the barcode and scanner to update the coupon ticket. A prototype of the application system built to be review and implement by the agency. Why barcode? Barcode is selected for this application due to the following reasons:

- Elements of the barcode is much smaller and lighter than RFID (Radio Frequency-Identification technology) tags, make it easier to use and generate

- Less costly because barcodes are directly stamped on the surface of any materials. Thus, only the price of ink considered expensive but still affordable

- Barcode are easily available and only require the barcode reader or scanner to process it and

- $\quad$ Barcode has the same function and accuracy of RFID tags

With the above advantages in mind, the system with barcode is suitable. Objective of this final year project is to develop the website for user registration and to produce the mobile application using android and barcode scanner for the local city council in Malaysia to use.

Literature review: Android system let us gain many of opportunities to develop something that useful to community even in small categories or parts. Technologies even from small but simple application can contribute with helping communities get through in daily life.

Group of researchers (Gowdal et al., 2017) build a prototype system that provide security using barcode system. At the entrance, camera took pictures of the driver and save in the database. This system could also detect vacant car parks. In a parking system built by researchers (Zalawadia, 2015) in focused on hardware design. Another application, Parkalot (2018) is a website to create a parking system on your own. It is easy because of friendly interface where user can access the website everywhere and create their own parking system. Easy to use facility parking booking and management system for your organization. The system required register and login for security and identification purpose. Figure 1 shows Parkalot.io screen captures.

Another application (Anonymous, 2019) using barcode scanner lets the customer make their own barcode scanner app and use the company web based barcode system. The application is available on Google Play and App Store. Figure 2 and 3 shows the screen captures of the said system application.

Parktron Technology Ltd (2018) a company in Taiwan provides many range of automated parking product systems. They used parking ticket solution using MIFARE IC card, barcode and ChipCoin. It uses barcode and has panel to scan also make payment for parking ticket. MIFARE IC technology is a contactless card system just like the usage of the Touch-n-go card in Malaysia. While barcode imitate the barcode (Code 128C), make use of the Ethernet and still print the ticket. ChipCoin made from a plastic but with a chip inside for saving data. No ticket is printed. Figure 4 is the Parktron parking system flow.

Comparison of the existing product with proposed prototype, Table 1, based on the selected features. The propose application have links for enforcement officers to monitor the parking rate.

Barcode system: Barcode system in Fig. 5, uses Universal Product Code (UPC) created to classify products for helping big retail and grocery stores in the USA. It was an idea from two persons bernard silver and Woodland in early of 1949 derived from the idea of the Morse code and movie soundtrack. Item in inventory can be trace quickly and efficient by using barcode to prevent from uncounted product.

The early barcode-scanning equipment uses a conventional lamp to illuminate product labels and a photomultiplier (a crude type of photoelectric cell) to read the light reflected off them. 
Table 1: Comparison of systems

\begin{tabular}{llll}
\hline Features & codeREADr & Propose barcode parking system & Parkalot.io \\
\hline Android/web base application & Android & Both & Web based \\
Scanner for barcode & Yes for mobile app & Yes for mobile app & No scanner, a reservation \\
Barcode in system & Yes & Yes & No \\
Hardware in system & Mobile phone & Mobile phone and Computer & Use of cloud \\
Internet requirement & Internet for storage & Yes & Yes for website \\
Security purpose & Register and login & Register and login & Login and registration \\
\hline
\end{tabular}

Access Control and
Ticket Validation
Services Scan History settings
Services inform you and define the way
scan data is collected, processed and
stored.
Asset Tracking
Attendance
Database Builder $>$
Mobile Security $>$

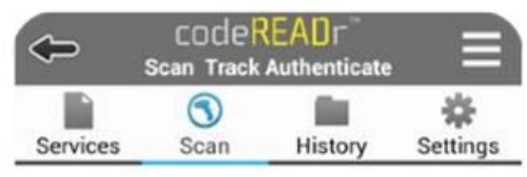

\section{Tap to Scan}
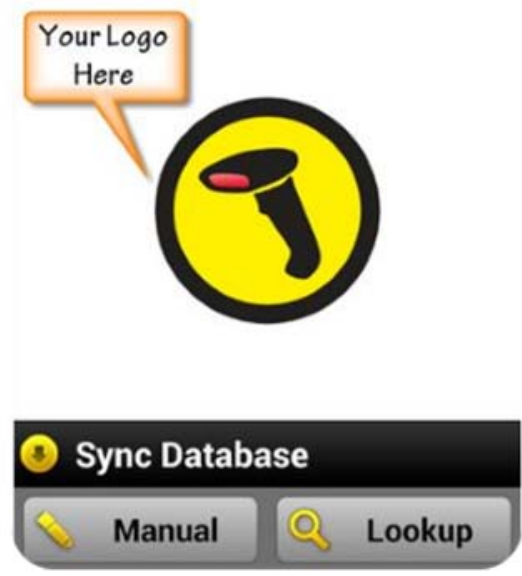

Fig. 2: codeREADr screen capture (Anonymous, 2019)
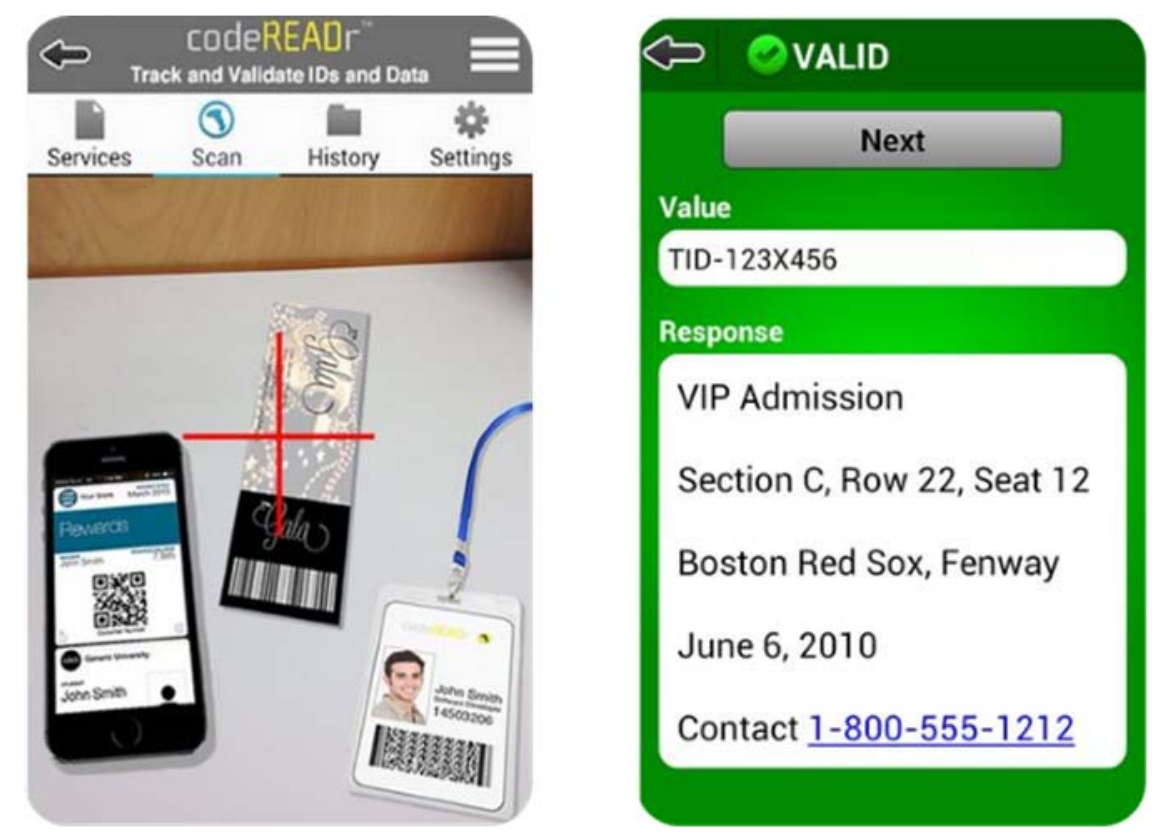

Fig. 3: codeREADr screen capture (Anonymous., 2019) 


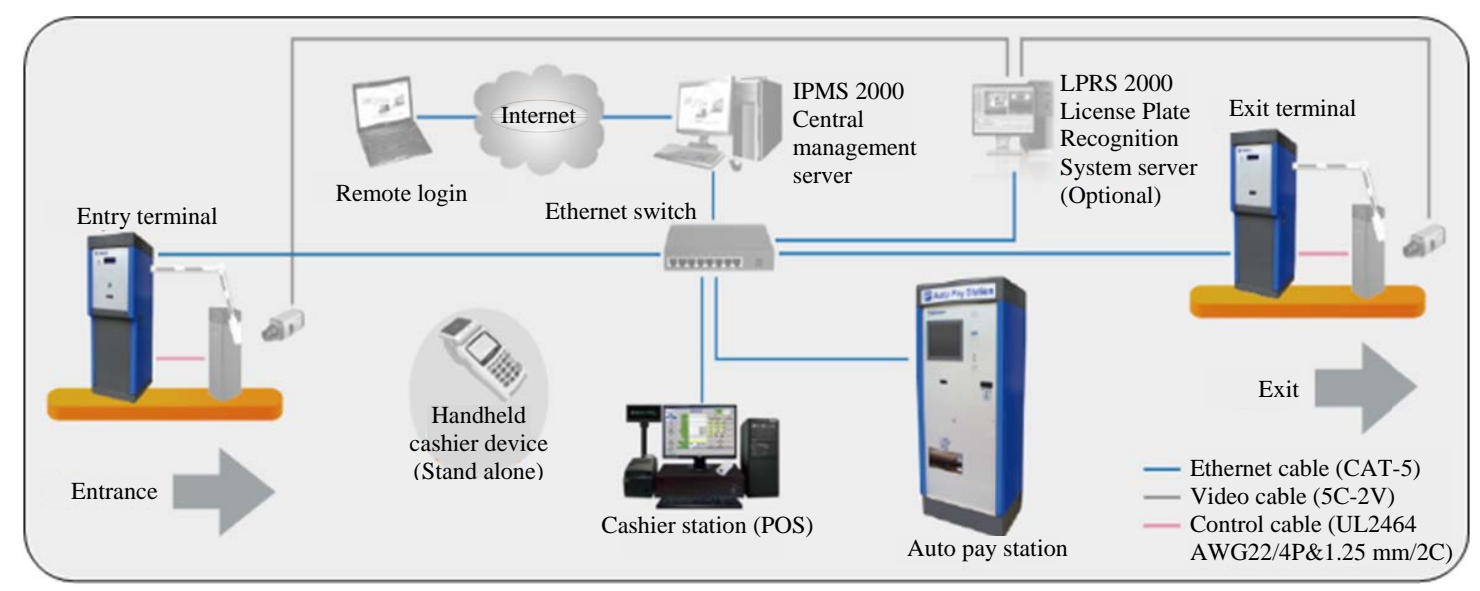

Fig. 4: Parktron parking system flow (Parktron Technology Ltd, 2018)

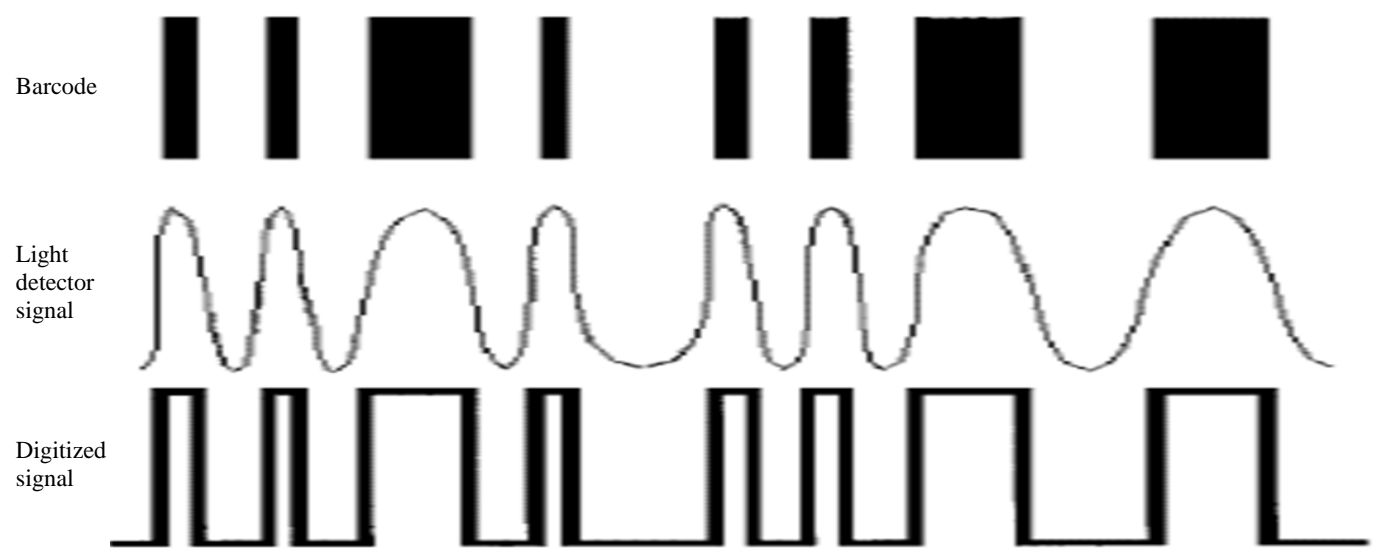

Fig. 5: Barcodes (Anonymous, 2014)

The system act to identify product with a specific code (number, alphabet, symbol) and not duplicate or redundant with other product barcode. Reliability on the barcode has proved for example in a shopping mall on counter site, every cashier provided with scanner and money machine. This scanner will scan the barcode in every item to count for their price and print in the receipt. After barcode being scan, information of price will be retrieve from the database.

Barcode code system has a unique symbol that only readable by specific scanner (Anonymous, 2014). It consist of a symbol such a black lines with several lines to keep a number as only readable by barcode scanner. The lines have a unique identification use for product purpose.

In Europe, the European Article Numbering (EAN) is used same as to UPC but consists of extra digit that identify from which country it originated. The process of reading barcode is shown in Fig. 6.

Common linear symbolizes include UPC/EAN, Interleaved 2 of 5 (1-5), Codabar, code 39 and code 128. code 39 shown there are consist of character inside the barcode include the number, symbol and alphabet. It has a characteristic that user can set the character include number, symbol, alphabet and code 8 (EAN-8) or 13(EAN-13) only consist of numerical digits.

Each code is for different implement or area for example code EAN use for regular industry like point-of-sale software while code 39 in big industry such automotive industry or electrical industry. According to Anonymous (2014) two-dimensional code is increasingly popular with the growth in telecommunication technology.

Types of barcode: There are two types of barcode: one dimension and two dimension, depicted in Fig. 7. One dimension barcode is a barcode having several black lines separated by space and thickness of barcode. The barcode will store the number and character regularly use in industry. It cannot be modify after it have been set for a security purpose.

Two-dimensional barcode name as Quick Response (QR) code. QR code is a new generation of barcode not only provide a simple and inexpensive method to present 
(a)

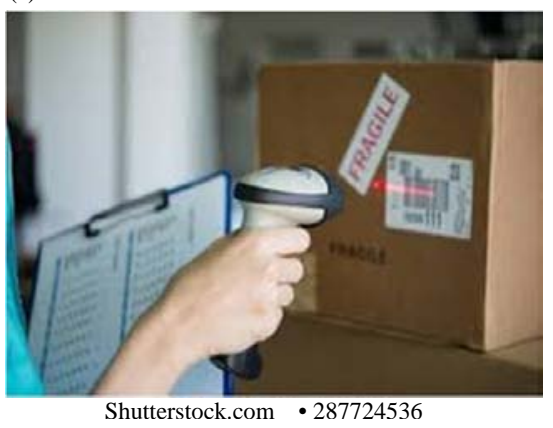

(b)

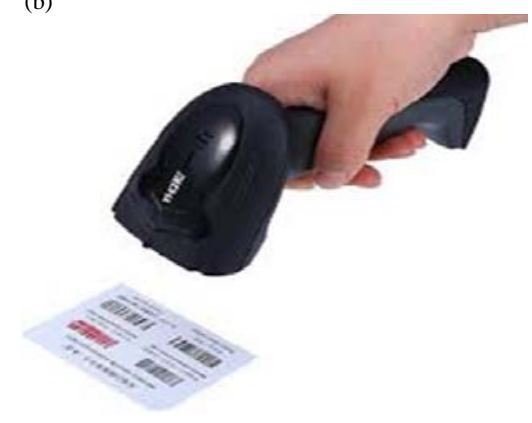

Fig. 6: Device read barcode (Anonymous, 2013)

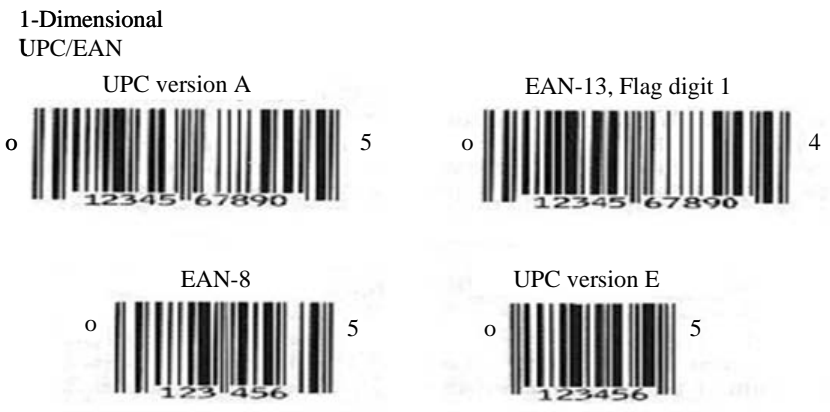

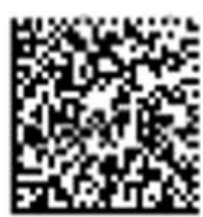

2-Dimensional

Fig. 7: 1 and 2 dimensional barcode system (Zalawadia, 2015)

diverse commerce data but also improve mobile user experience by reducing their inputs. The shape of QR code was integrate from lines to shape in square.

The difference is in retrieving information where two-dimensional cannot use the laser scanner to get the information. It only can be captured by the scanner with functional relate to image capture. The height as well as the length of the symbol stores information for both types. "A 2-dimensional code is often referred to as a stacked symbology or multi-row code" quoted from (Anonymous, 2014)

As internet technology evolving, so does other technology related application, industries and human. New things or application produced by person or industries that can be used by others, continuously. Barcode system also experiencing the same thing as many 2-dimensional symbologies produce for personal reason or industry related use. However, not all can be used as there are certain industry standards that have to be followed.

\section{MATERIALS AND METHODS}

Method used: The prototype project starts with reading tasks on similar projects, Fig. 8 on next page, finding the differences about the current coupon ticket system used by local city council in order to rectify and further develop the system.

The coupon ticket system make use of paper and manually issued by local city council. Users have to buy the coupon tickets in bulk in order to use it then manually scratch and displayed in the vehicle.

This prototype project make use of Rapid Application Development (RAD) methodology, shown in Fig. 9, for the system development of this prototype project. It is chosen due to the usage of structured techniques and prototyping to refine user requirements and design the final system. RAD is one of the software methods development which requires little or no planning during the prototype software. Principally, this methodology use prototypes to present to the users as a starting point for an iterative development process.

Using structured techniques the developer first builds a conceptual prototype based on the initial high level data and business process models and predefined high level business requirements. Cutover is where a part of system being validated by the user and developer whether the project are successful or not.

Software requirement specification: Requirements for this project taken from stakeholder (Local City Council and users), functional and non-functional requirement are considered. Based from these, Table 2 is the outcome of functional requirement.

Table 2 showed the functional requirement for mobile application. Functional requirement is to specify on function of component such as expected input and output. A function is describe as a set of inputs, the behavior and outputs. Functional requirement also illustrate the feature of system on what the system can do or cannot do. 


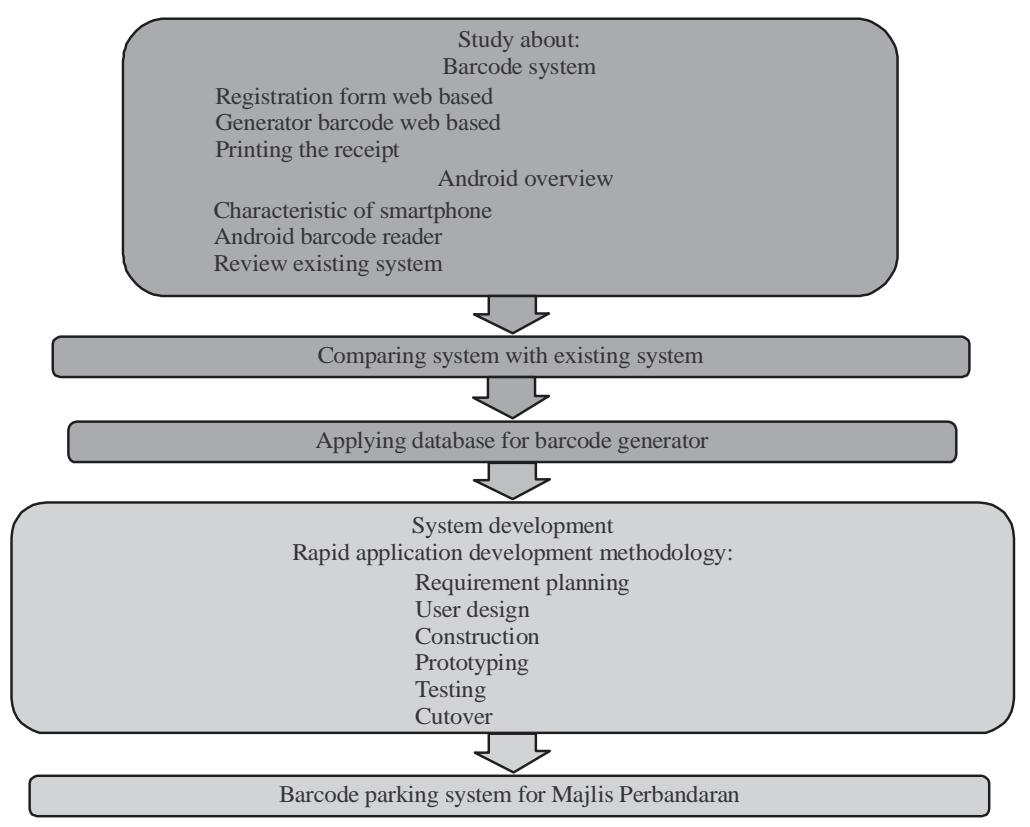

Fig. 8: Research steps

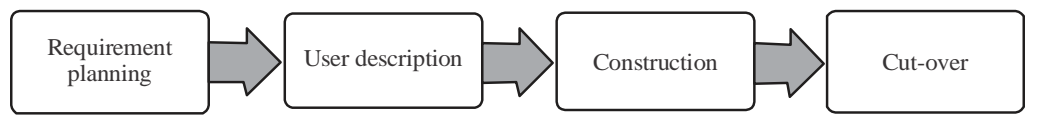

Fig. 9: RAD Model (Kumar and Bhatia, 2014)

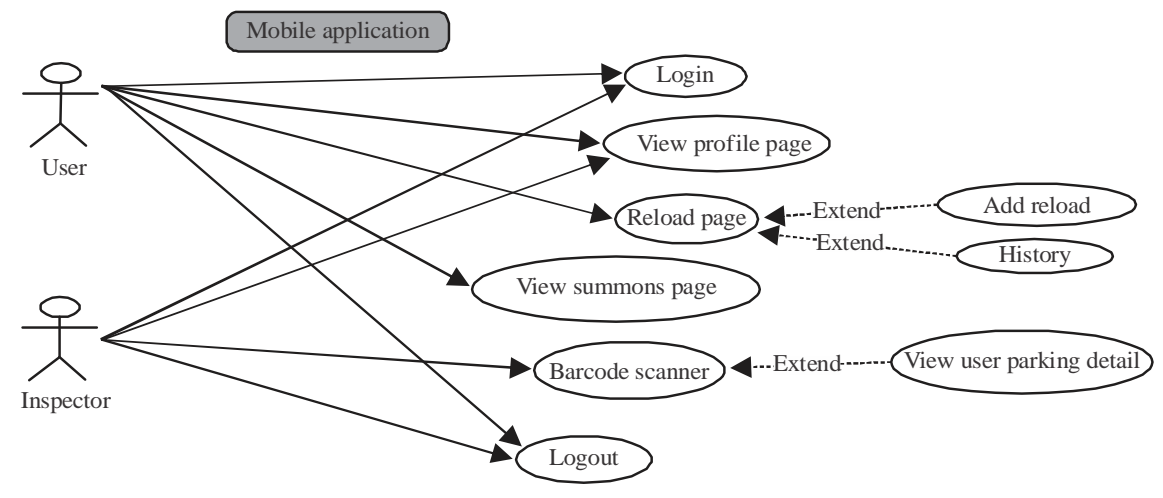

Fig. 10: Use case diagram for registering new user

Table 2: Website functional requirement

\begin{tabular}{ll}
\hline Functional requirement & Requirement description \\
\hline Website & Must connect to database \\
Legin and registration & Any user can register and login \\
Vummon registration & $\begin{array}{l}\text { User can register, generate and print barcode } \\
\text { User able to view summons details in the } \\
\text { summons page }\end{array}$ \\
View profile & $\begin{array}{l}\text { User can update password, view, delete and } \\
\text { edit their profile }\end{array}$ \\
\hline
\end{tabular}

It is important to know the capability of system when error occurs (Fig. 10). Non-functional requirements describe how the system works, description of other characteristics, features and quality that clarify a
Table 3: Mobile application functional requirement Functional requirement Requirement description

Login Download and login to mobile app

Reload page Can reload into the e-wallet

Parking ticket User can pay ticket parking by hour option

and select their own vehicle to pay

Change password User can change password

Barcode scanner app Inspector can scan barcode on the ticket Summon Inspector can issue summon

satisfactory system which is include safety, security and usability, reliability and performance requirements. Table 3 listed the non-functional requirement for this project. 
Table 4: Non-functional requirement for barcode parking system

\begin{tabular}{|c|c|}
\hline Products & Requirement description \\
\hline \multirow{14}{*}{$\begin{array}{l}\text { Website and mobile } \\
\text { application }\end{array}$} & Performance \\
\hline & The capability of website and mobile app to connect and interact with database \\
\hline & The confirmation of inserting and manipulating data in database successfully \\
\hline & Searching of data correctly for every single login have be made \\
\hline & Validation message for every access whether it similar with data in database or not \\
\hline & Ensure the generating of barcode are not similar for every registration vehicle \\
\hline & Print for reload and barcode confirm successful \\
\hline & Output for parking ticket and wallet are correctly in stress mode tester \\
\hline & Usability \\
\hline & $\begin{array}{l}\text { Website and mobile application are easy to use as provide with description on 'how to use'. The interface also friendly user } \\
\text { as user can understand simply without having any mistaken. }\end{array}$ \\
\hline & Reliability \\
\hline & $\begin{array}{l}\text { Website and mobile app can use wisely by user as website it come with bootstrap that provide with mobile view version, } \\
\text { and mobile app that only required internet connection to use it }\end{array}$ \\
\hline & Portability \\
\hline & Mobile application were being develop to make user easy use on paying their ticketing parking fee \\
\hline \multirow{5}{*}{$\begin{array}{l}\text { Website page, button } \\
\text { and manipulating data }\end{array}$} & Operational requirement \\
\hline & $\begin{array}{l}\text { Function of every page include profile, user profile, inspector registration, frequently asked question, vehicle registration, } \\
\text { summons, and about us page were test under operational requirement. }\end{array}$ \\
\hline & Button for every page and make sure it does not come with error. \\
\hline & Manipulating data such button print, edit profile and delete vehicle function as well without any error. \\
\hline & Ensure the button function relate and have connection with database. \\
\hline \multirow{7}{*}{$\begin{array}{l}\text { Mobile app for user } \\
\text { and inspector }\end{array}$} & Security requirement \\
\hline & Login in mobile application to differentiate between user and inspector even use same mobile application. \\
\hline & Ensure the profile information same as login profile use \\
\hline & Ensure scanner barcode only can be access by inspector and not by user. \\
\hline & Verification \\
\hline & $\begin{array}{l}\text { Ensure payment for parking ticket success with any problem rise such payment has be deduct but ticket parking are not show } \\
\text { it up }\end{array}$ \\
\hline & The wallet added after user has made a reload \\
\hline
\end{tabular}

Three features or products were considered for this project as shown in Table 4 in the non-functional requirements setting.

Unified Modelling Language (UML): Figure 10 showed a sample of the use case diagram for mobile application development.

UML is one of the way to describe the functionality of system and interconnection between upper class and lower class such inheritance, override and overload process. In software documentation, it is a critical part to identify requirement before develop project started. For this project use case diagram selected to describe the functionality of the screen design for each pages.

\section{RESULTS AND DISCUSSION}

Design and implementation: Figure 11 and 12 are the screenshot of the prototype system for website application.

Mobile application design: Figure $13-16$ are the screenshot for the mobile application of barcode parking system. The web application for this prototype project developed using Ionic framework and Laravel framework, local host used is HeidiSQL for the database. Most of the time data is stored using Cloud. Laravel, a platform for creating web based application combines other frameworks in other languages such as Sinatra, ASP.NET and MVC. While for mobile application development,
Ionic is the best choice as it is a free software, open source and suitable for native iOS, Android and the web.

Testing and results: Website application used functionality, usability, interface and compatibility testing while mobile application tested on usability, compatibility, services and performance testing.

Test case: Figure 17-20 are the sample of acceptance test done for this prototype.

Results: About 20 public users have tested the system website and mobile on the prototype phase and construction phase to gather information on understanding user regarding to barcode parking system for local city council. Survey with questionnaires were done:

- From the survey while they used the prototype system

- About 65\% agreed should use the prototype barcode parking system

- About $70 \%$ of them found that the website and mobile application are interesting.

- About 50\% found that the instruction are clear and easy to understand

- About $75 \%$ said that the registration, login and vehicle registration are easy to use and understand, $20 \%$ said moderate and 5\% said not easy to use

- About $100 \%$ success recorded for the scanner for inspector 
(a)

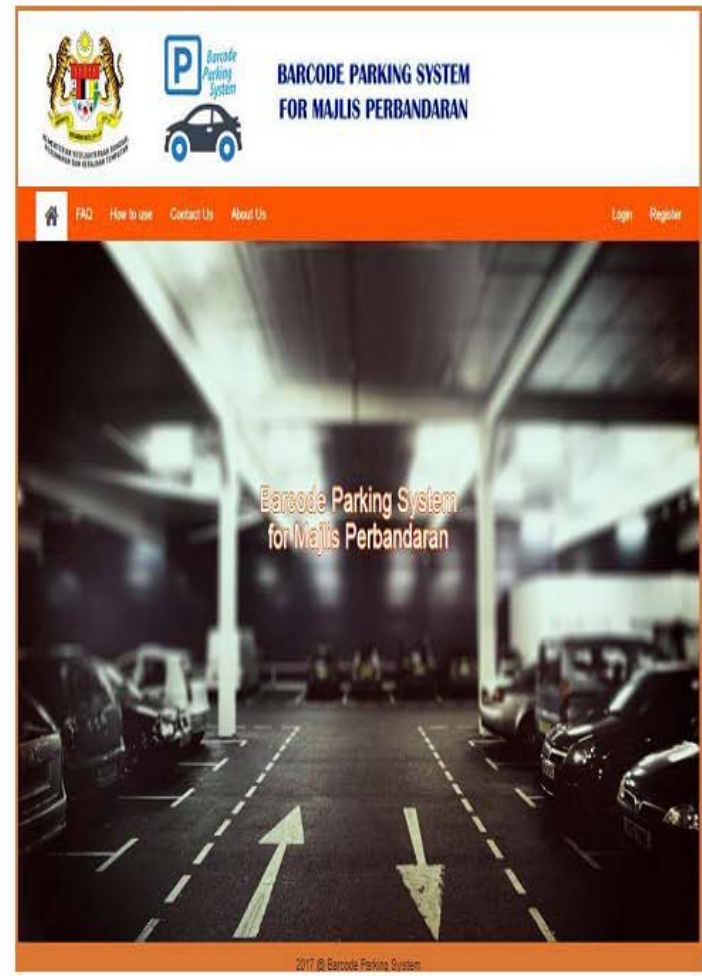

(b)

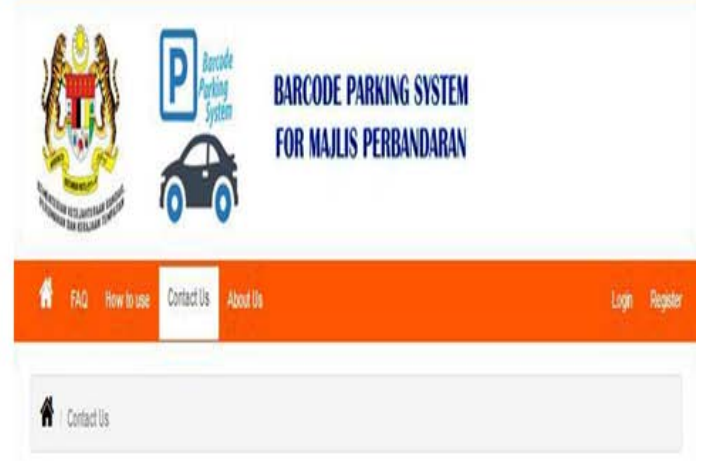

Contactlls

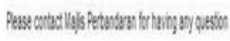

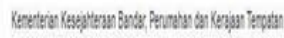

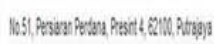

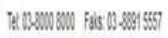

wawbitoun

Fig. 11: Home page screenshot

(a)

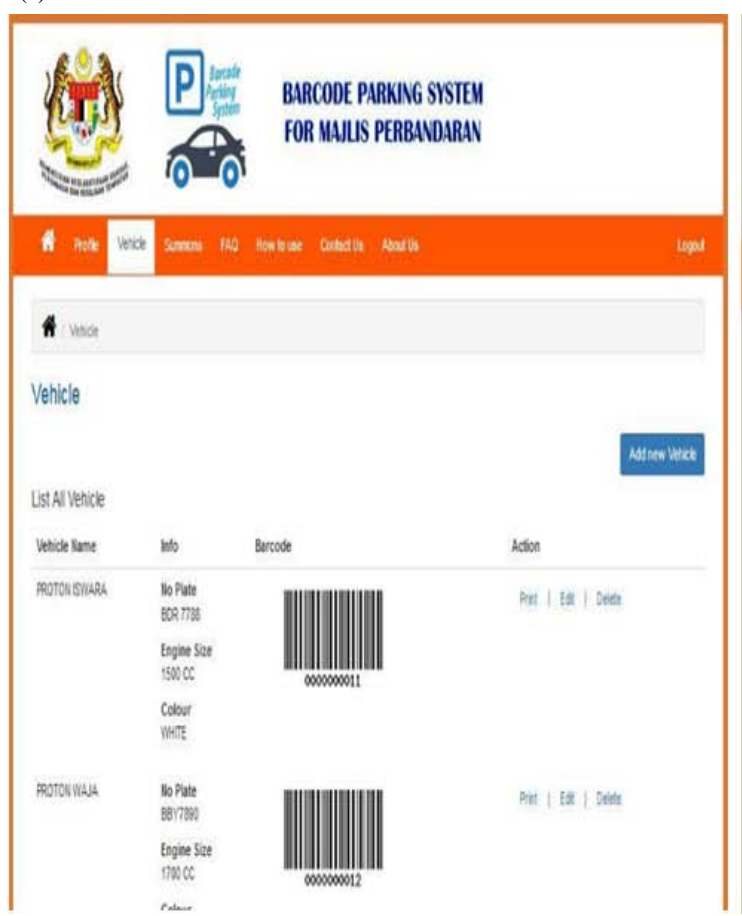

(b)
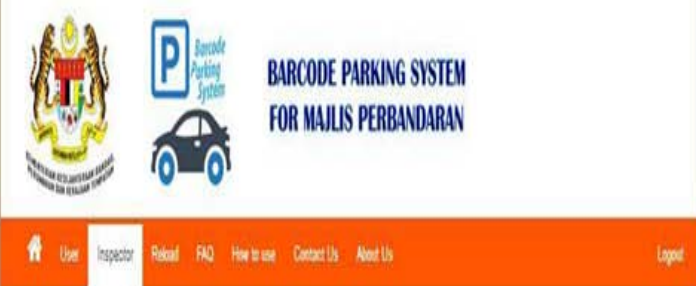

A

Inspector

Listillinspector

\begin{tabular}{|c|c|c|c|c|}
\hline lint & sturt & Enal & the & ketor \\
\hline \multirow[t]{5}{*}{ in } & ingit & nathoricion & 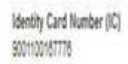 & Et I Dete \\
\hline & & & Alont llunste & \\
\hline & & & NHWX: & \\
\hline & & & Notrs & \\
\hline & & & $4 \pi$ & \\
\hline
\end{tabular}

Fig. 12: Vehicle and city council enforcement officer’s page 
(a)

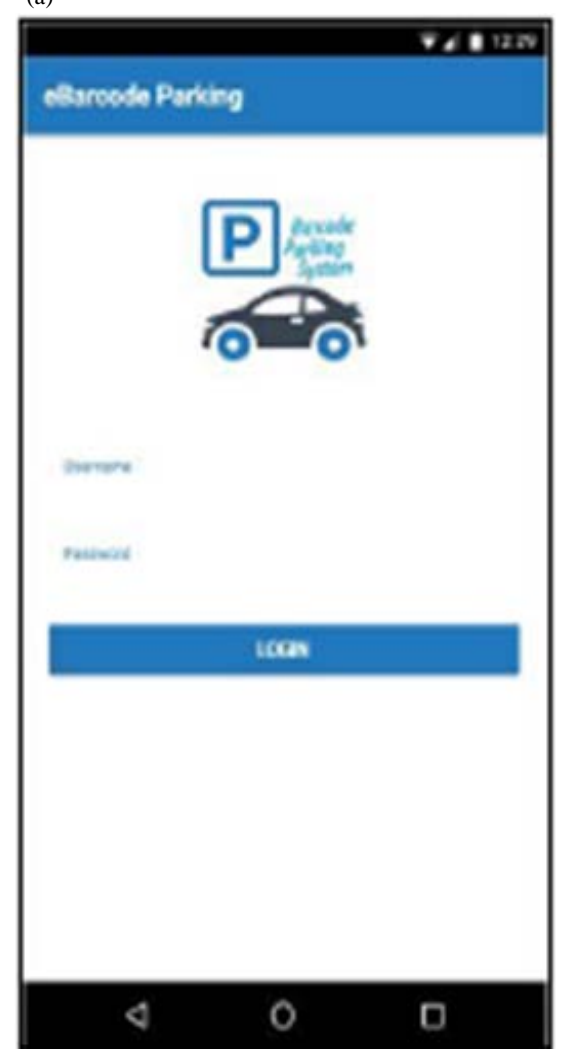

Fig. 13: Mobile application of barcode parking system

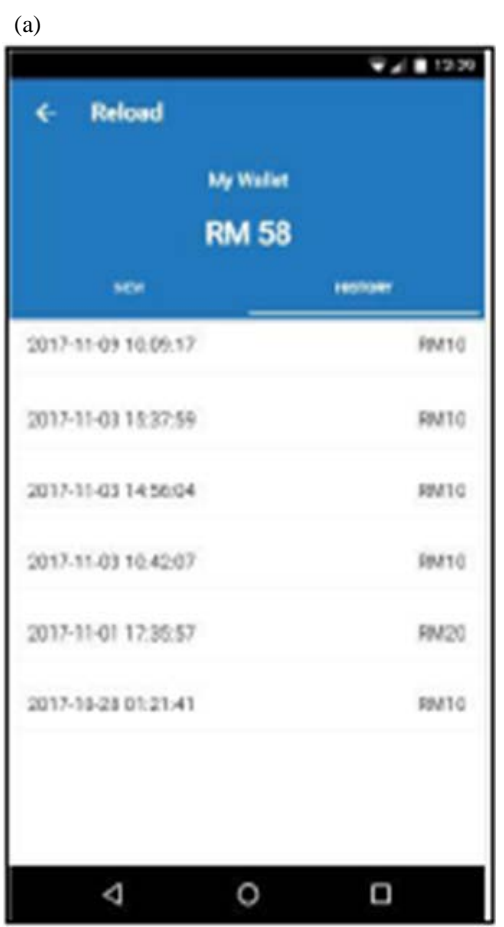

Fig. 14: Screen shot of e-Wallet (b)

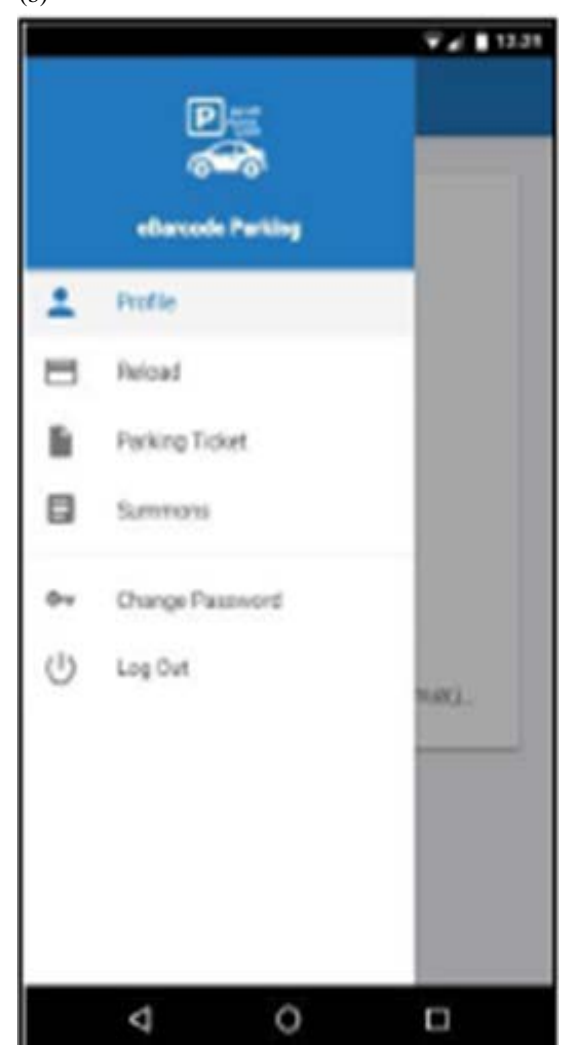

(b)

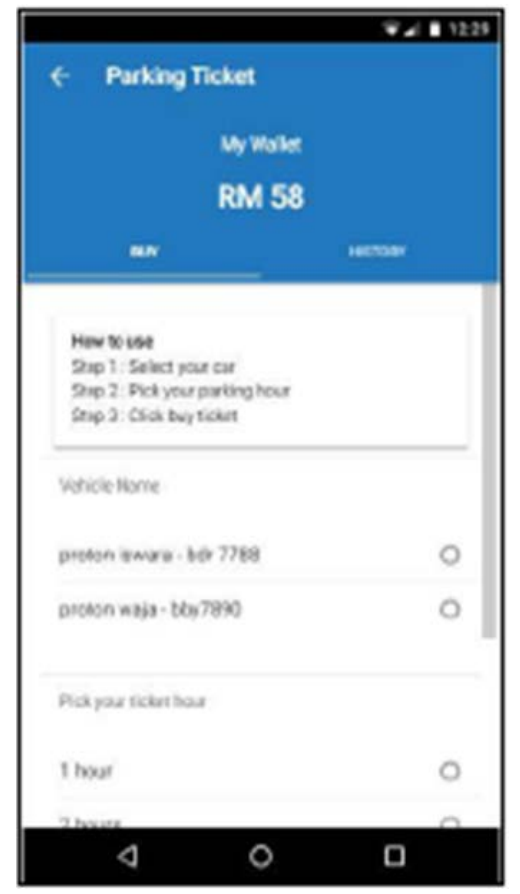



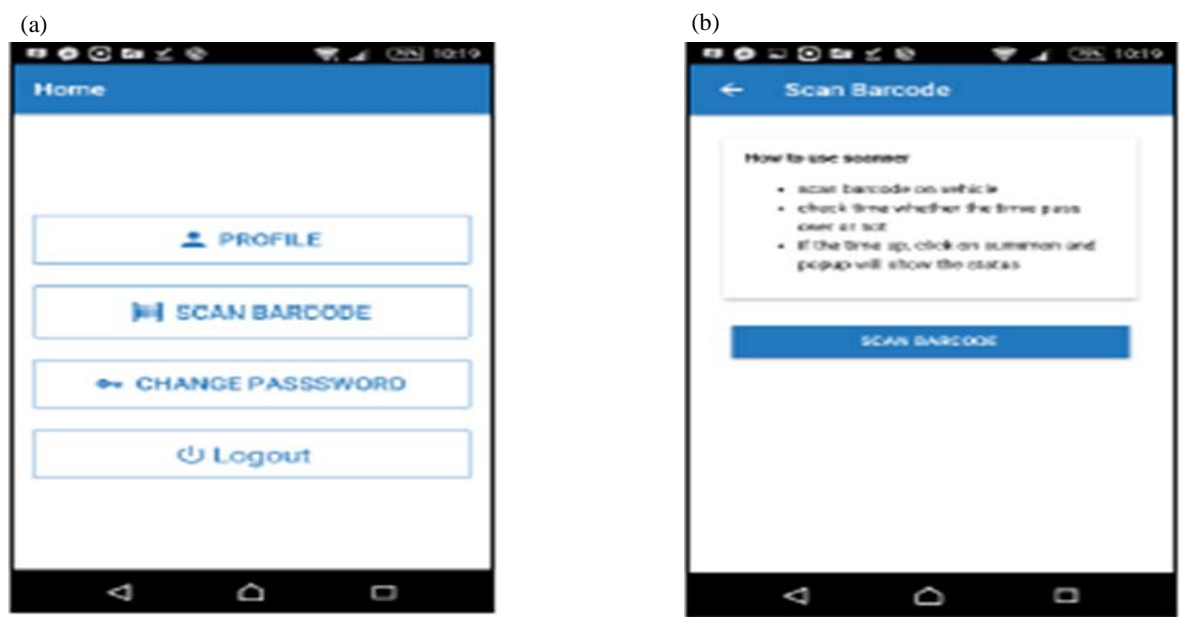

Fig. 15: Profile screen shot

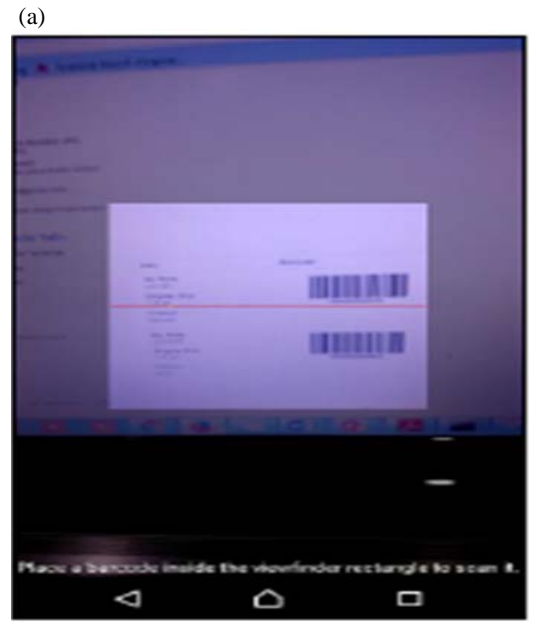

(b)

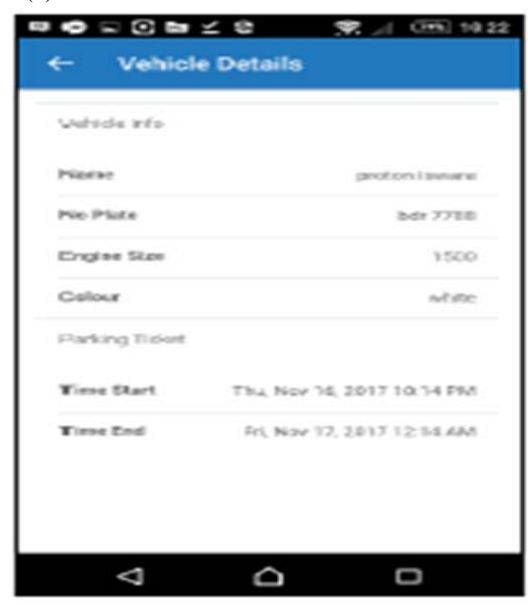

Fig. 16: Barcode ccanner

\begin{tabular}{|c|c|c|c|c|c|c|}
\hline \multirow{2}{*}{\multicolumn{2}{|c|}{$\begin{array}{l}\text { Test Case } \\
\text { System }\end{array}$}} & \multicolumn{2}{|l|}{ TC-05 } & $\begin{array}{l}\text { Test Case } \\
\text { Name }\end{array}$ & \multicolumn{2}{|c|}{ interrace testing } \\
\hline & & \multicolumn{2}{|c|}{$\begin{array}{l}\text { Barcode parking } \\
\text { system (mebsite) }\end{array}$} & subsystem & & \\
\hline \multicolumn{2}{|c|}{ Designed by } & \multicolumn{2}{|c|}{$\begin{array}{l}\text { Mohamad Zul Helmi } \\
\text { bin Azilla }\end{array}$} & $\begin{array}{l}\text { Design } \\
\text { Date }\end{array}$ & \multicolumn{2}{|c|}{$5 / 4 / 2017$} \\
\hline \multicolumn{2}{|c|}{ Executed by } & \multicolumn{2}{|c|}{ Maziqan Hanun } & $\begin{array}{l}\text { Execution } \\
\text { Date }\end{array}$ & \multicolumn{2}{|c|}{$21 / 10 / 2017$} \\
\hline \multicolumn{7}{|c|}{ Related Requ } \\
\hline \multicolumn{7}{|c|}{ Test in other } \\
\hline \multicolumn{7}{|c|}{ Pre-condition } \\
\hline Step & \multicolumn{2}{|l|}{ Action } & \multicolumn{2}{|l|}{$\begin{array}{l}\text { Expected } \\
\text { Response }\end{array}$} & $\begin{array}{l}\text { pass' } \\
\text { Fail }\end{array}$ & comment \\
\hline 1 & \multicolumn{2}{|c|}{ Browse in chorme } & \multicolumn{2}{|c|}{ Website work properiy } & pass & \\
\hline 2 & \multicolumn{2}{|c|}{ Browse in firetox } & \multicolumn{2}{|c|}{ Website work property } & Pass & \\
\hline 3 & \multicolumn{2}{|c|}{$\begin{array}{l}\text { Browse website in } \\
\text { android misphone } \\
\text { (xiomi and } \\
\text { tablet (Samsung } \\
\text { tablet } S 2 \text { ) }\end{array}$} & \multicolumn{2}{|c|}{$\begin{array}{l}\text { Website work property } \\
\text { with their runctionality }\end{array}$} & pass & \\
\hline 4 & \multicolumn{2}{|c|}{$\begin{array}{l}\text { Browse in ias } \\
\text { phone (iphone } 7 \text { ) }\end{array}$} & \multicolumn{2}{|c|}{$\begin{array}{l}\text { Website work properiy } \\
\text { with los version } 11.3 \\
\text { (latest version) }\end{array}$} & pass & \\
\hline 5 & \multicolumn{2}{|c|}{ icon position } & \multicolumn{2}{|c|}{$\begin{array}{l}\text { Website icon does not } \\
\text { change in dirrerent } \\
\text { browser and devices }\end{array}$} & pass & \\
\hline \multicolumn{7}{|c|}{ post-condition } \\
\hline \multicolumn{2}{|l|}{ Note } & & & & & \\
\hline
\end{tabular}

Fig. 17: Interface test form 


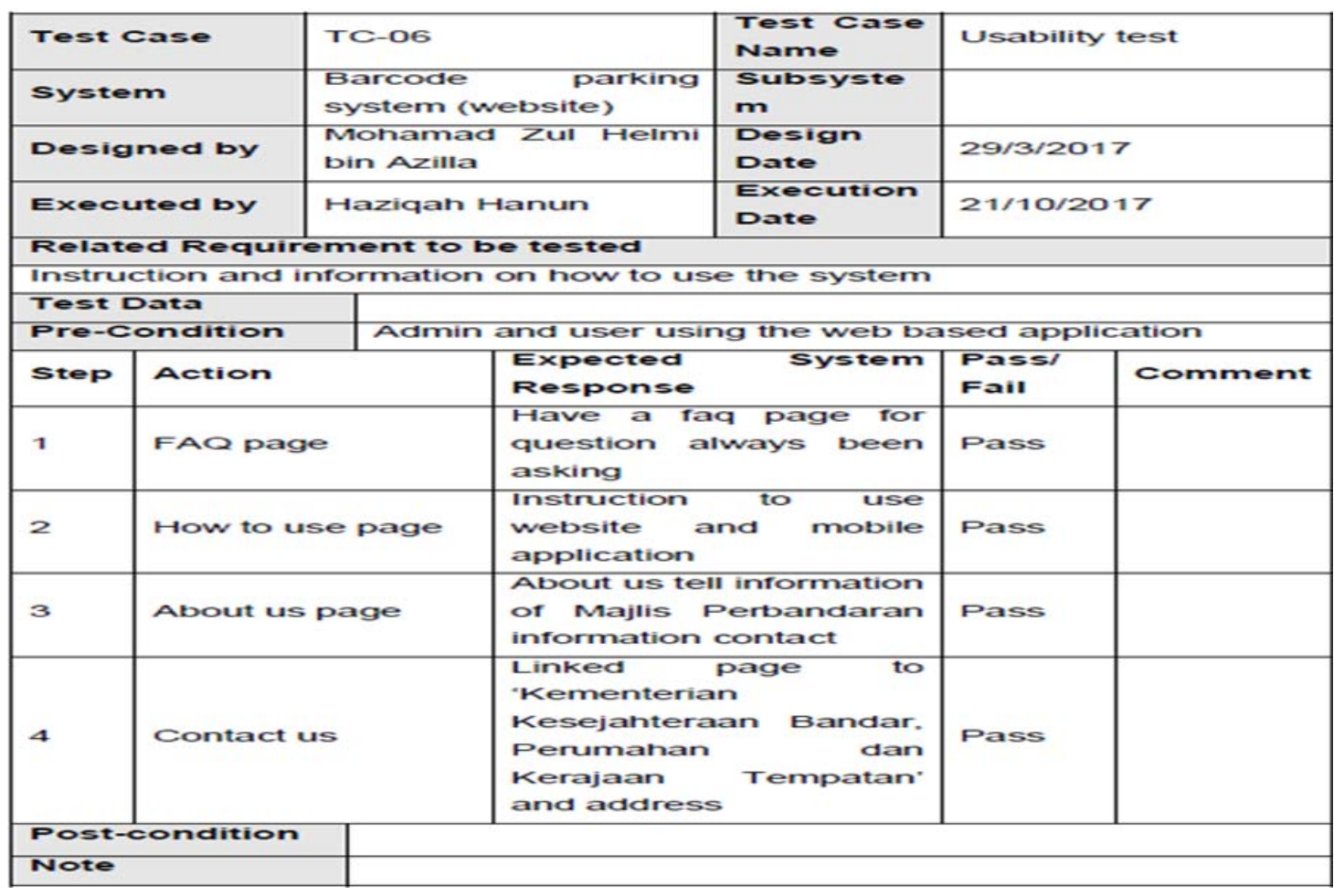

Fig. 18: Usability test form

\begin{tabular}{|c|c|c|c|c|c|c|}
\hline \multicolumn{2}{|c|}{ Test Case } & \multicolumn{2}{|l|}{ TC-09 } & \begin{tabular}{|l|} 
Test Case \\
Name
\end{tabular} & \multicolumn{2}{|c|}{ Compatibility test } \\
\hline \multicolumn{2}{|c|}{ System } & \multicolumn{2}{|c|}{$\begin{array}{ll}\text { Barcode } & \text { parking } \\
\text { system } & \text { (Mobile } \\
\text { Application) } & \end{array}$} & $\begin{array}{l}\text { Subsyste } \\
\text { m }\end{array}$ & & \\
\hline \multicolumn{2}{|c|}{ Designed by } & \multicolumn{2}{|c|}{$\begin{array}{l}\text { Mohamad Zul Helmi } \\
\text { bin Azilla }\end{array}$} & \begin{tabular}{|l} 
Design \\
Date
\end{tabular} & \multicolumn{2}{|c|}{$28 / 4 / 2017$} \\
\hline \multicolumn{2}{|c|}{ Executed by } & \multicolumn{2}{|c|}{ Haziqah Hanun } & \begin{tabular}{|l|} 
Execution \\
Date
\end{tabular} & \multicolumn{2}{|c|}{$21 / 10 / 2017$} \\
\hline \multicolumn{7}{|c|}{ Related Requirement to be tested } \\
\hline \multicolumn{7}{|c|}{ Test application mobile with different android version } \\
\hline \multicolumn{7}{|c|}{ Test Data } \\
\hline \multicolumn{7}{|c|}{ User using the mobile application } \\
\hline Step & \multicolumn{2}{|l|}{ Action } & \multicolumn{2}{|c|}{$\begin{array}{|ll|}\text { Expected } & \text { System } \\
\text { Response } & \end{array}$} & \multirow{2}{*}{\begin{tabular}{|l|}
$\begin{array}{l}\text { Pass/ } \\
\text { Fail }\end{array}$ \\
Pass \\
\end{tabular}} & Comment \\
\hline 1 & \multicolumn{2}{|c|}{$\begin{array}{l}\text { Test on android } 2 \\
\text { (Gingerbread) }\end{array}$} & \multicolumn{2}{|c|}{$\begin{array}{l}\text { Cannot install as not } \\
\text { supported requirment }\end{array}$} & & \\
\hline 2 & \multicolumn{2}{|c|}{$\begin{array}{l}\text { Test on android } \\
4-4.2 \text { (Ice cream } \\
\text { sandwich) }\end{array}$} & \multicolumn{2}{|c|}{$\begin{array}{l}\text { Support with success } \\
\text { installation and take } \\
\text { around } 24 \text { second to } \\
\text { install }\end{array}$} & Pass & \\
\hline 3 & $\begin{array}{l}\text { Test on } \\
\text { (Lolipop } \\
\text { (Mashm }\end{array}$ & $\begin{array}{c}\text { android } 5 \\
\text { and } 6 \\
\text { allow) }\end{array}$ & $\begin{array}{l}\text { Support wi } \\
\text { installation } \\
\text { around } 10 \\
\text { install }\end{array}$ & $\begin{array}{l}\text { ith success } \\
\text { and take } \\
\text { second to }\end{array}$ & Pass & \\
\hline 4 & $\begin{array}{l}\text { Test o } \\
\text { simulato } \\
\text { (bluesta } \\
\text { android }\end{array}$ & android & $\begin{array}{l}\text { Supported a } \\
\text { run functior } \\
\text { part }\end{array}$ & $\begin{array}{l}\text { and properly } \\
\text { n of every }\end{array}$ & Pass & \\
\hline \multicolumn{7}{|c|}{ Post-condition } \\
\hline \multicolumn{2}{|l|}{ Note } & & & & & \\
\hline
\end{tabular}

\begin{tabular}{|c|c|c|c|c|c|c|}
\hline \multicolumn{2}{|c|}{ Test Case } & \multicolumn{2}{|c|}{ TC-10 } & $\begin{array}{l}\text { Test Case } \\
\text { Name }\end{array}$ & \multicolumn{2}{|c|}{ Service testing } \\
\hline \multicolumn{2}{|c|}{ System } & \multicolumn{2}{|c|}{$\begin{array}{|ll|}\text { Barcode } & \text { parking } \\
\text { system } & \text { (Mobile } \\
\text { Application) } & \\
\end{array}$} & $\begin{array}{l}\text { Subsyste } \\
\text { m }\end{array}$ & & \\
\hline \multicolumn{2}{|c|}{ Designed by } & \multicolumn{2}{|c|}{$\begin{array}{l}\text { Mohamad Zul Helmi } \\
\text { bin Azilla }\end{array}$} & \begin{tabular}{|l} 
Design \\
Date
\end{tabular} & \multicolumn{2}{|c|}{$29 / 3 / 2017$} \\
\hline \multicolumn{2}{|c|}{ Executed by } & \multicolumn{2}{|c|}{ Haziqah Hanun } & $\begin{array}{l}\text { Execution } \\
\text { Date }\end{array}$ & \multicolumn{2}{|c|}{$21 / 10 / 2017$} \\
\hline \multicolumn{7}{|c|}{ Related Requirement to be tested } \\
\hline \multicolumn{7}{|c|}{ Run application in offline and online mode } \\
\hline \multicolumn{7}{|c|}{ Test Data } \\
\hline \multicolumn{2}{|c|}{ Pre-Condition } & \multicolumn{5}{|c|}{ User using the mobile application } \\
\hline Step & \multicolumn{2}{|l|}{ Action } & $\begin{array}{l}\text { Expected } \\
\text { Response }\end{array}$ & System & \begin{tabular}{|l|} 
Pass/ \\
Fail
\end{tabular} & Comment \\
\hline 1 & \multicolumn{2}{|c|}{ Login page } & $\begin{array}{l}\text { Run in } \\
\text { cannot run i }\end{array}$ & $\begin{array}{l}\text { online and } \\
n \text { offline }\end{array}$ & Pass & \\
\hline 2 & \multicolumn{2}{|c|}{ Reload page } & $\begin{array}{l}\text { Cannot relo } \\
\text { and history r } \\
\text { offline }\end{array}$ & $\begin{array}{l}\text { ad in offline } \\
\text { not update in }\end{array}$ & Pass & \\
\hline 3 & \multicolumn{2}{|c|}{ Pay ticket } & $\begin{array}{l}\text { Online moc } \\
\text { ticket } \\
\text { Offline mo } \\
\text { pay ticket } \\
\text { handling po }\end{array}$ & $\begin{array}{l}\text { e: can pay } \\
\text { de: cannot } \\
\text { and error } \\
\text { pup }\end{array}$ & Pass & \\
\hline 4 & \multicolumn{2}{|c|}{ Error handling } & $\begin{array}{l}\text { Loading ico } \\
\text { if there is } \\
\text { connection }\end{array}$ & $\begin{array}{l}\text { n will popup } \\
\text { no internet }\end{array}$ & Pass & \\
\hline \multicolumn{7}{|c|}{ Post-condition } \\
\hline \multicolumn{2}{|l|}{ Note } & & & & & \\
\hline
\end{tabular}

Fig. 19: Compatibility and service testing 


\begin{tabular}{|c|c|c|c|c|c|c|}
\hline \multicolumn{2}{|c|}{ Test Case } & \multicolumn{2}{|l|}{ TC-13 } & $\begin{array}{l}\text { Test Case } \\
\text { Name }\end{array}$ & \multicolumn{2}{|c|}{$\begin{array}{lr}\text { Barcode } & \text { scanner } \\
\text { and } & \text { summon } \\
\text { button } & \end{array}$} \\
\hline \multicolumn{2}{|c|}{ System } & \multicolumn{2}{|c|}{$\begin{array}{l}\text { Barcode parking } \\
\text { system (Mobile } \\
\text { Application) }\end{array}$} & Subsystem & & \\
\hline \multicolumn{2}{|c|}{ Designed by } & \multicolumn{2}{|c|}{$\begin{array}{l}\text { Mohamad Zul Helmi } \\
\text { bin Azilla }\end{array}$} & $\begin{array}{l}\text { Design } \\
\text { Date }\end{array}$ & \multicolumn{2}{|c|}{$25 / 7 / 2017$} \\
\hline \multicolumn{2}{|c|}{ Executed by } & \multicolumn{2}{|c|}{ Haziqah Hanun } & $\begin{array}{l}\text { Execution } \\
\text { Date }\end{array}$ & \multicolumn{2}{|c|}{$21 / 10 / 2017$} \\
\hline \multicolumn{7}{|c|}{ Related Requirement to be tested } \\
\hline \multicolumn{7}{|c|}{ Test on scan barcode and summon functionality } \\
\hline \multicolumn{7}{|c|}{ Test Data } \\
\hline \multicolumn{2}{|c|}{ Pre-Condition } & \multicolumn{5}{|c|}{ Inspector using the mobile application } \\
\hline Step & \multicolumn{2}{|l|}{ Action } & \multicolumn{2}{|c|}{$\begin{array}{l}\text { Expected System } \\
\text { Response }\end{array}$} & \begin{tabular}{|l|} 
Pass \\
\\
Fail
\end{tabular} & Comment \\
\hline 1 & \multicolumn{2}{|c|}{$\begin{array}{l}\text { Barcode } \\
\text { scanner }\end{array}$} & \multicolumn{2}{|c|}{$\begin{array}{l}\text { Barcode scanner work } \\
\text { proper with proper auto } \\
\text { rotation }\end{array}$} & Pass & \\
\hline 2 & \multicolumn{2}{|c|}{$\begin{array}{l}\text { Instruction of } \\
\text { barcode } \\
\text { scanner }\end{array}$} & \multicolumn{2}{|c|}{$\begin{array}{l}\text { Provide with on how to use } \\
\text { the barcode scanner }\end{array}$} & Pass & \\
\hline 3 & \multicolumn{2}{|c|}{$\begin{array}{l}\text { Retrieve data } \\
\text { from barcode } \\
\text { scanner }\end{array}$} & \multicolumn{2}{|c|}{$\begin{array}{l}\text { Data can be retrieve and } \\
\text { certainty of information were } \\
\text { correctly }\end{array}$} & Pass & \\
\hline 4 & \multicolumn{2}{|c|}{$\begin{array}{l}\text { Detail of vehicle } \\
\text { information }\end{array}$} & \multicolumn{2}{|c|}{$\begin{array}{l}\text { Vehicle infomation can be } \\
\text { show }\end{array}$} & Pass & \\
\hline
\end{tabular}

Fig. 20: Functionality and interface testing

\section{CONCLUSION}

The prototype application functions successfully tested by mobile users and it performed well during the implementation and testing phases. The application is useful for local council to deploy but to enforce the agency to use it is another story. The management of city council is not centralize and some parts of the country still prefer to use the coupon ticket system. It is considered successful prototype as it provide the developer to enhance their skill of programming, testing and developing application for mobile phones which is not available freely. The application is useful as it help users to monitor their own parking and its cashless element through the use of electronic payment.

\section{RECOMMENDATIONS}

It may have some drawbacks on the font, background and language difficulty, captured from the user's response in distributed questionnaires. Future work for the application would be deploying it in another language for example Mandarin or Bahasa Melayu, national language of Malaysia and to other mobile phone operating system.

\section{REFERENCES}

Anonymous, 2013. Stock assets to power your creativity: Explore over 300 million royalty-free images, stock footage clips and music tracks. Shutterstock Inc., New York, USA. https://www.shutterstock.com/

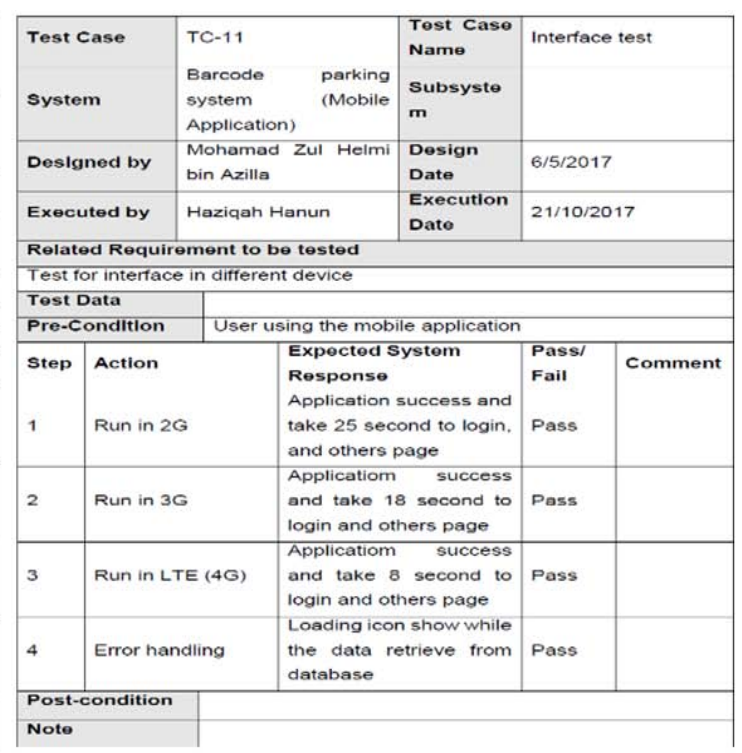

Anonymous, 2014. Bar code basics: Basic concepts for barcode and atomatic identification beginners. American Barcode and RFID, Phoenix, Arizona, USA. https://www.abr.com/wp-content/uploads/ 2014/04/barcode-basics.pdf

Anonymous, 2016. Parking. Manjung Municipal Council Stadium, Seri Manjung, Malaysia. http://www.mpm.gov.my/en/citizens/services/parking

Anonymous, 2019. Smart barcode Scanning Apps with integrated, cloud-based SaaS platform AIDC as a service. Skycore LLC., Waltham, Massachusetts, USA. https://www.codereadr.com/about/

BPS., 2019. Parking coupons. British Psychological Society, Leicester, UK. http://www.borneoparking. com/parking-coupons/

Bernama, 2019. Caj parkir MBSA naik 20 sen. Malaysiakini, Petaling Jaya, Kuala Lumpur. https://www.malaysiakini.com/news/469828

Bhosale, S., P. Durgashi and P. Pawar, 2015. RFID based digital parking management system. Int. J. Adv. Found. Res. Sci. Eng., Vol. 1,

Ch'ng, B., 2017. MBPJ offers two ways to pay for parking. Star Media Group Berhad, Petaling Jaya, Malaysia. https://www.thestar.com.my/ metro/community/2017/08/31/mbpj-offers-two-way s-to-pay-for-parking-scratchanddisplay-coupons-tocomplement-payanddisplay-system

Dogo, E.M., A. Ahmed and M.O. Adelakun, 2016. A model for an enterprise automated RFID-based pay and park system. Proceedings of the International Conference on Information and Communication Technology and its Applications, November 28-30, 2016, Federal University of Technology, Minna, Nigeria, pp: 177-183. 
Dorjee, K.T., D. Rasaily and B. Cintury, 2016. Rfid-based automatic vehicle parking system using microcontroller. Int. J. Eng. Trends Technol. (IJETT), 32: 191-194.

Gowda1, S.R., R.R. Raj and P.R. Varun Gowda, 2017. Barcode based parking management system. Int. Res. J. Eng. Technol. (IRJET), 4: 1648-1651.

Kumar, G. and P.K. Bhatia, 2014. Comparative analysis of software engineering models from traditional to modern methodologies. Proceedings of the 2014 4th International Conference on Advanced Computing \& Communication Technologies, February 8-9, 2014, IEEE, Rohtak, India, pp: 189-196.

Mogarkar, R.O. and M.T. Gulhane, 2016. Smart city based smart parking system in metropolitan area using R.F.I.D. IOSR. J. Electr. Electron. Eng., 11: 71-73.

Mudey, G.V. and D.V. Rojatkar, 2015. Automated vehicle parking in indian context. Int. J. Thesis Projects Dissertations (IJTPD), 3: 22-26.

Nair, V., 2017. Faulty machines make parking a pain in KL. Star Media Group, Malaysia. https://www.thestar.com.my/metro/community/201 7/05/11/dealing-with-faulty-parking-machines-in-kl/
Nikhitkumar, S. Abhijith, S. Jajoo, S.G.R. Prasad and J. Mungara, 2015. Low cost intelligent parking management and guidance system. Int. J. Eng. Comput. Sci., 4: 11297-11300.

Parkalot, 2018. Make workplace car parking fair, easy and frustration-free. Parkalot, Krakow, Poland. https://parkalot.io/

Parktron Technology Ltd, 2018. Parktron-parking management system-auto pay station. Parktron Technology Ltd, Taiwan. http://www.parktron.com/

Patel, C., M. Swami, P. Saxena and S. Shah, 2015. Rotary automated car parking system. Int. J. Eng. Sci. Innovative Technol. (IJESIT), 4: 408-415.

Song, J. and J.S. Lee, 2016. Positioning method using a vehicular black-box camera and a 2D barcode in an indoor parking lot. J. Korea Inst. Inf. Commun. Eng., 20: 142-152.

Tekade, P., R. Mhaskar, P. Surywanshi, A. Shirgurkar, A. Panmalkar, and R. Patil, 2017. QR code implementation in car parking locator. Int. J. Innovative Res. Comput. Commun. Eng., 5: 4125-4131.

Zalawadia, P.R., 2015. Barcode based automated parking management system. Int. J. Sci. Res. Dev., 2: 1446-1450. 